\title{
The relationship between language learning strategies and thinking styles of Iranian EFL learners
}

Khodae Balestane, Mahmood $\bowtie$

Islamic Azad University, Urmia, Iran (Khodae.m@gmail.com)

Hashemnezhad, Hossein

Islamic Azad University, Khoy, Iran (h_hashemnezhad2000@yahoo.com)

Javidi, Shahrooz

Urmia University, Iran (shjavidi2003@yahoo.com)

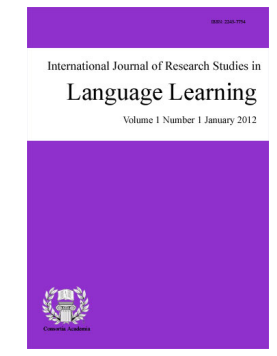

ISSN: $2243-7754$ Online ISSN: 2243-7762

OPEN ACCESS

\section{Abstract}

Educators can design better subject materials and distinguish students' characteristics if they comprehend learners thinking and learning styles. Therefore, this study aimed at substantiating the relationship between Iranian EFL learners' thinking styles and their language learning strategies. To this end, measures of the language learning strategies of 251 non-randomly chosen Iranian EFL learners (169 female and 82 male) studying English at Urmia and Tabriz Islamic Azad universities were obtained using questionnaire on language learning strategies. Additionally, the Thinking Styles Inventory, a self-report test, was used to evaluate participants' thinking styles. The Pearson product-moment correlation analysis indicated a statistically significant relationship between the two sets of measures $(\mathrm{r}=0.6, p \leq$ 0.05). Further analysis demonstrated that thinking styles and language learning strategies have positive correlation with gender. The result of the independent t-test revealed that there was a significant difference between male and female in their language learning strategies in favor of males. Implications mention that teaching methods and materials should be adjusted to the learning and thinking styles of students.

Keywords: thinking styles; language learning strategies; styles; learning strategies; EFL 


\section{The relationship between language learning strategies and thinking styles of Iranian EFL learners}

\section{Introduction}

It cannot be easily explained why the same learner may have completely different levels of achievement in different subjects. When different factors affecting learning were examined, style was considered to be one of the important factors by researchers. Ever since, the style construct was considered, researchers have been exploring the nature of cognitive, thinking, language learning styles and strategies and their effects on performance in both academic and nonacademic settings. Thinking styles and language learning strategies are two essential scopes. Are students' language learning strategies and thinking styles related with gender? Researchers have demonstrated the efficiency of language learning strategies in learners' language use and learning (O'Malley \& Chamot, 1990; Oxford, 1993).

Oxford (1990) mentioned that strategies are prominent for language learning "because they are tools for active, self-directed involvement, which is essential for developing communicative competence" (p. 1). According to Cohen (1998) language learning strategies are "the conscious thoughts and behaviors used by learners with the explicit goal of improving their knowledge of the target language" (p. 68). Scholars categorized language learning strategies differently. Learning strategies classified by O'Malley and Chamot (1990) as metacognitive, cognitive, and social/affective. Metacognitive learning strategies deal with "higher-order executive skills that may entail planning, monitoring, or evaluating the success of a learning activity" (p. 44), and cognitive learning strategies "operate directly on incoming information, manipulating it in ways to enhance learning" (ibid.), at last social/affective strategies that "represent a broad grouping that involves either interaction with another person or ideational control over affect" (ibid.).

Oxford (1990) categorized learning strategies as direct and indirect. She defined direct strategies as "strategies that directly involve the target language in the sense that they require mental processing of the language" (p. 37), while indirect strategies "provide indirect support for language learning through focusing, planning, evaluating, seeking opportunities, controlling anxiety, increasing cooperation and empathy, and other means" (p. 151). Direct strategies involve memory (for the storage and retrieval of information), cognitive (to link latest information with former information) and compensation strategies (for defeating gaps in L2 knowledge); and indirect strategies consist of metacognitive (for planning and evaluating), affective (focus on the emotional regulation), and social strategies (contribute to interaction with others).

As Oxford and Nyikos (1989) note, factors like language learning level, field of specialization, national origin, and language teaching methods are related to language learners choice of strategies, but others such as motivation, age and sex have not received enough research attention. Gender was one factor that has been explored by many researchers. Oxford (1993) stated that studies showed that females were likely to use general study strategies, affective strategies, social strategies and certain conversational or functional practice strategies more often than males. Studies considering gender and EFL strategy use demonstrated females as more strategy users than males (for example, Green \& Oxford, 1995; Oxford, 1993). However, gender differences are not necessarily universal. For example, Tran's (1988) study revealed less strategy use of Vietnamese female immigrants to the U.S. in comparison to males.

The results of Wharton (2000) study on learning strategies of 678 university students in Singapore showed that males used more strategies than females. Studies examining gender differences disclosed that gender had not an effect on strategy choice of EFL learners, in other words, there was no significant difference in strategy use among males and females (Shmais, 2003; Rahimi, Riazi, \& Seyf, 2004; Endaweke, 2008; McMullen, 2008). Gavriilidou and Papanis (2010) found no significant effect of gender in strategy use on 117 randomly chosen 
Greek-speaking students (54 boys and 63 girls) attending the Democritus University of Thrace. A study by Anugkakul (2011) to compare language learning strategies (LLS) employed by 72 Chinese and Thai students demonstrated that gender and nationality had a significant effect on the students' use of overall LLS. The findings thus far provided rich insights into interpreting the gender issues in the studies of LLS. Besides that, most studies were done in ESL/EFL setting and only a few were undertaken in Iranian language learning context.

Language learning strategies of learners can be related to the variable of thinking styles. The term thinking styles is defined as one's habitual patterns or preferred ways of thinking while doing something (Sternberg, 1993, 1997). Thinking styles concern the question of how one thinks which is different from how well one thinks. Sternberg (1997) asserted that "what happens to us in life depends not just on how well we think, but also on how we think" (p. 18). Sternberg (1997) classified 13 thinking styles under 5 dimensions of functions, forms, levels, scopes and leaning. Further he described these dimensions as follows. First, the function dimension includes legislative (enjoy the freedom of using own ways of doing things), executive (follow rules to solve problems), judicial (evaluate and analyze different views). Second, the form dimension consists of monarchic (only works on one task at a time), hierarchic (set priorities for tasks), oligarchic (like to work on multitasks and set equal prominence but may not enjoy priorities), anarchic (do things in unsystematic ways and unable to set priorities). Third, the level dimension has global style (pay attention to the overall picture and macro problem), local style (dealing with details, microscopic and concrete problems). Fourth, the scope dimension covers internal (introvert, like to work alone), external (extrovert, like working with other people). Finally, the two styles in leaning dimension are liberal (likes tasks that consist of novelty) and conservative (sticks to the old rules and traditional methods).

Thinking styles can be affected by a variety of factors like culture, gender, age, parental styles, schools, different jobs, birth order and social and economic status (Imamipour \& Seyf, 2003). Sternberg (1997) believed that two aspects of culture are relevant here: (a) some societies are likely to be more rewarding of certain styles than of others. (b) The respective natures of individualistic and collectivistic cultures may lead to different styles. However, there are no adequate supporting data for these suggestions. Gender is relevant to thinking styles. Sternberg (1997) declared that, men used higher frequency of styles than women and rated themselves as more legislative, global, internal and less judicial. The ways the parents react to their children's questions and what they encourage and reward at home reflect in the style of the child, Sternberg (1997). Various styles are rewarded in different schools and occupations, e.g. executive, local and conservative styles are probably rewarded at schools (Ibid). Sternberg suggests that thinking styles are related with creativity processes, problem solving and decision making (Imamipour \& Seyf, 2003).

Sarvghad, Rezaee, and Masomi (2010) conducted a study to investigate the relationship between thinking styles and self-efficiency of Pre-university students in Shiraz. They reported a significant correlation between females' self- efficiency and all thinking styles except internal and global thinking style but males did not reveal any correlation between thinking styles and self-efficiency. Golshokooh, Ahadi, Enayate, Asgare, Heydari, and Pasha (2009) examined the relationship between thinking styles, achievement and creativity with entrepreneur of university students. The result of the study indicated that legislative and local thinking style, creativity and achievement were predicator of entrepreneur. Imamipour and Seyf (2003) investigated the correlation of thinking styles of the university and high school students with creativity and achievement. The study indicated that there was a significant relationship between age, grade and achievement. As if the older were the students the less had they monarchic, oligarchic, anarchic, local and conservative thinking styles but higher legislative and hierarchic thinking styles. The results also showed that females surpassed males in the use of legislative, executive, judicial, monarchic, anarchic, local, global, external and liberal thinking styles. Regarding students different levels this study discovered that the higher the grade the less their monarchic, oligarchic, anarchic, local, and conservative thinking styles.

Hartwick, Ford, and Ullmon (1998, cited in Khoeiny, 2006) investigated thinking styles of 125 university students, and found that males had more legislative thinking style in comparison with females who showed 
Khodae Balestane, M., Hashemnezhad, H., \& Javidi, Sh.

executive thinking style. This result is maybe because of culture, education system or parents thinking styles. Zhang (2000) explored the learning motive and strategy use of two groups of American university students (67, 65). She found that thinking styles like liberal, judicial, legislative and hierarchical styles had a positive relationship with deep approach scales, but negative relationship with surface approach scales.

Yet few, if any, empirical studies have investigated the relationship between languages learning strategies and thinking styles in Iranian context. With a growing language learners' population, it is critical that research be conducted to explore new ways positively matching learning strategies with thinking styles. Matching thinking styles with language learning strategies of learners is critical to the future success of education and language learning. Furthermore, the findings will inform TEFL methodology, material and syllabus development, learner teaching, teacher training.

\subsection{Significance of the study}

The way individuals learn or understand new information and their preferred learning methods and thinking styles have been a popular subject in the past. In recent years, research on learning styles has provided teachers and also students with a different view of learning and how to apply this view in their classroom and lives. Different students learn language differently because they have different personal characteristics and thinking styles. The importance of these personal characteristics to ESL teachers is that the same teaching method or technique may be affective for some learners and not so much effective for others (Hyland, 1993). It is, therefore, crucial to find out the ways through which students prefer to learn the language, hoping that such information help Iranian EFL teachers to become more effective in their teaching.

There are a lot of theoretical supports for the idea that mismatch are common and they negatively affect learning, learner motivation and attitude (Felder, 1995), yet few, if any, empirical studies have researched the relationship between language learning strategies and thinking styles in Iranian context. There is a pressing need for research; Moreover, the findings are useful for material and syllabus development, teacher training and learner teaching. Research on learning and thinking styles will provide teachers and students with a different view of learning and teaching within the classroom. Furthermore, it can help teachers to identify the learning and thinking preferences of their students and then teach in a way that is appealing to most students. That way they will be on a more direct path toward achieving their goal. It also aids syllabus planners and material designers to work out on language learning syllabi that are in line with students' perceptions and experiences.

Information about learning and thinking styles can help faculty become more sensitive to the differences students bring to the classroom. It can also serve as guidance in thoughtfully and systematically designing learning experiences that match students' thinking and learning styles depending on the teachers' purposes. Despite the increasing popularity of research on language learning and thinking styles preferences, this topic is still a new research area in Iran. Most teachers are not aware of the ways their students prefer learning the language or even if they know the students preferences, they pay little, if any attention to them. Some teachers acknowledge the fact that in conducting language learning activities consult learners, but are unable to respond to students' learning needs. These matters are of paramount importance and need to be taken into consideration by teachers, in general, and Iranian EFL teachers, in particular. Therefore, research on the relationship between language learning strategies and thinking styles of Iranian EFL students, and the extent to which they are recognized by teachers, and whether they take them into account or not, seem to be of high necessity.

\subsection{Research questions and hypotheses}

More specifically, this study aims at seeking answers to the following research questions:

1. Is there a relationship between language learning strategies employed by Iranian (EFL) university students and their thinking styles? 
The relationship between language learning strategies and thinking styles of Iranian EFL learners

2. Is there a relationship between language learning strategies employed by Iranian (EFL) university students and their gender?

3. Is there a relationship between thinking styles employed by Iranian (EFL) university students and their gender?

In line with objectives, the following alternative hypotheses are drawn:

1. There is a positive relationship between language learning strategies employed by Iranian (EFL) university students and their thinking styles?

2. There is a positive relationship between language learning strategies employed by Iranian (EFL) university students and their gender.

3. There is a positive relationship between thinking styles employed by Iranian (EFL) university students and their gender.

\section{Method}

\subsection{Participants}

A total number of 251 Iranian college students were involved in this study. The participants were all English majors in Urmia and Tabriz Islamic Azad universities. The questionnaire was distributed to regular classes that represent the different study durations (freshmen, sophomores, juniors). The sample was not fairly balanced, consisting of 82 males and 169 females; the female-male ratio was approximately 2 to 1 , favoring female students this sample was non-randomly chosen. A majority of the students $37.1 \%$ were freshmen, $31.87 \%$ were juniors, and $31.07 \%$ were sophomores. They were asked to respond to the questionnaire on Thinking Styles Inventory (Sternberg \& Wagner, 1992) and Oxford's (1990) Strategy Inventory for Language Learning (SILL). Besides, they were required to response to the part of background information on their gender and grade. The participants' ages ranged from 19 to 22 years, with a mean range of 20.45 years. Students were from the Faculty of Humanities, including English literature and English translation majors so as it is clear they had studied some English books at the university and were familiar with it and had knowledge about it.

\subsection{Instrumentation}

Data collection was done by using two inventories. The first inventory was Oxford's LLS (1990). The second was Sternberg and Wagner's (1992) TSI. Since there was doubt that the subjects might have problems with understanding the content of the questionnaire in English and to remove any probable language barriers, all sections including LLS (50 items), the TSI (65 items) along with the section on the part of background information on their gender and grade were translated into Persian. The translated versions of the questionnaires were critically examined for their accuracy, precision, and authenticity of the translation and the necessary modifications were made. Both of the questionnaires rated based on 5-point Likert scale from $1=$ "never" to $5=$ "always". To elicit Language Learning Strategies of participants the Strategy Inventory for Language Learning (SILL) was used. The alpha co-efficient for reliability of the SILL is 0.92 (Griffiths, 2007) and content validity is 0.99 (Oxford \& Burry-Stock, 1995). This questionnaire has six types of strategies, involving memory strategies (items 1 to 9), cognitive strategies (items 10 to 23), compensation strategies (items 24 to 29), metacognitive strategies (items 30 to 38 ), affective strategies (items 39 to 44 ) and social strategies (items 45 to 50).

The Thinking Styles Inventory (Sternberg \& Wagner, 1992), a self-report test consisting of 65 items, was used to evaluate student participants' thinking styles. The inventory has 13 scales with five items on each scale. These 13 scales correspond to the 13 thinking styles described in Sternberg's theory of mental self-government. Sternberg's theory describes 13 thinking styles that fall within the following five dimensions of mental 
Khodae Balestane, M., Hashemnezhad, H., \& Javidi, Sh.

self-government: functions (legislative [items 5, 10, 14, 32, 49], executive [items 8, 11, 12, 31, 39], and judicial [items 20, 23, 42, 51, 57] styles), forms (hierarchic [items 4, 19, 25, 33, 56], oligarchic [items 27, 29, 30, 52, 59], monarchic [items 2, 43, 50, 54, 60], and anarchic [items 16, 21, 35, 40, 47] styles), levels (global [items 7, 18, 38, 48, 61] and local [items 1,6, 24, 44, 62] styles), scopes (internal [items 9, 15, 37, 55, 63] and external [items 3, $17,34,41,46]$ styles), and learning (liberal [items 45, 53, 58, 64, 65] and conservative [items 13, 22, 26, 28, 36] styles).

\subsection{Procedure and data collection}

Data collection took place during the first semester of the academic year 2011- 2012. The questionnaires were distributed to classes representing the different levels (freshmen, sophomores, juniors) during the regular class meetings. At the beginning of the session, a short explanation of the purpose of study, time allocation, and instructions for completing the questionnaires provided. Meanwhile, both questionnaires were distributed at the same time to the participants. Both questionnaires took an average of 35 minutes to finish under complete conditions of anonymity and confidentiality. Data analysis was carried out using the Statistical Package for Social Sciences (SPSS, version 19) statistical program to obtain descriptive and inferential statistics.

\section{Results and discussion}

To find the relationship between thinking styles and language learning strategies the students' data were submitted to Pearson correlation. Table 1 depicts the computed correlation coefficient as 0.005 which is significant at 0.05 level of significance $(r=0.005, p \leq 0.05)$. In fact, the two variables are positively correlated.

Table 1

The correlation between Thinking Styles and Language Learning Strategies

\begin{tabular}{llrr}
\hline \multicolumn{1}{c}{ Items } & & Learning & Thinking \\
\hline Learning & Pearson Correlation & 1 & $.176^{* *}$ \\
& Sig. (2-tailed) & & .005 \\
& $\mathrm{~N}$ & 251 & 251 \\
\hline \multirow{2}{*}{ Thinking } & Pearson Correlation & $.176^{* * *}$ & 1 \\
& Sig. (2-tailed) & .005 & 251 \\
\hline
\end{tabular}

Note. ${ }^{* *}$ Correlation is significant at the 0.01 level (2-tailed)

To examine whether there was difference between male and female participants in the use of language learning strategies. The means and standard deviations for both genders were computed, followed by t-test to discover the differences between both groups in using Language Learning Strategies. Descriptive Statistics were examined for each of the two groups i.e. male and female in order to examine and compare the mean scores and standard deviations across the groups. Table 2 shows that at a significance level of .05 there was difference between male and female participants in memory, cognitive, evaluating, planning, and social strategies. As it can be seen in Table 2 there is a little difference between males and females in terms of strategy choice. But the results obtained from t-test analysis (Table 2.1) revealed that at $<0.05$ level of significance with 249 degrees of freedom, males used memory strategy with $\mathrm{t}=3.731, p<0.000$ and cognitive with $\mathrm{t}=4.122, p<0.000$, also they tended to use compensation with $\mathrm{t}=2.081, p<0.036$ and metacognitive with $\mathrm{t}=2.504, p<0.013$. In affective and social strategy use no difference was found between males and females.

Table 2

Descriptive statistics for males and females related to the choice of language learning

\begin{tabular}{llrlcc}
\hline & Gender & $\mathrm{N}$ & Mean & $S D$ & $S E$ \\
\hline Learning & Female & 169 & 171.40 & 23.474 & 1.806 \\
& Male & 82 & 172.30 & 32.096 & 3.544 \\
\hline
\end{tabular}


The relationship between language learning strategies and thinking styles of Iranian EFL learners

Table 2 ... continue

Descriptive statistics for males and females related to the choice of language learning

\begin{tabular}{llrccc}
\hline & Gender & $\mathrm{N}$ & Mean & $S D$ & \multicolumn{1}{c}{$S E$} \\
\hline Memory & Female & 169 & 27.89 & 4.760 & .366 \\
& Male & 82 & 30.20 & 4.197 & .463 \\
\hline Cognitive & Female & 169 & 47.59 & 9.000 & .692 \\
& Male & 82 & 52.61 & 9.142 & 1.010 \\
\hline Compensation & Female & 169 & 19.90 & 4.411 & .339 \\
& Male & 82 & 21.24 & 5.519 & .609 \\
\hline Metacognitive & Female & 169 & 35.65 & 5.791 & .445 \\
& Male & 82 & 37.71 & 6.699 & .740 \\
\hline Affective & Female & 169 & 18.89 & 3.688 & .284 \\
& Male & 82 & 18.21 & 3.192 & .353 \\
\hline Social & Female & 169 & 21.55 & 4.662 & .359 \\
& Male & 82 & 21.78 & 4.335 & .479 \\
\hline
\end{tabular}

Table 2.1

T-Test for males and females related to the choice of Language Learning Strategies

\begin{tabular}{lrrrrr}
\hline \multicolumn{1}{c}{ Items } & \multicolumn{1}{c}{ S } & Sig. & $t$ & $d f$ & Sig. (2-tailed) \\
\hline Memory & 1.573 & .211 & -3.731 & 249 & .000 \\
Cognitive & 1.015 & .315 & -4.122 & 249 & .000 \\
Compensation & .765 & .383 & -2.081 & 249 & .038 \\
Metacognitive & 17.631 & .000 & -2.504 & 249 & .013 \\
Affective & 2.438 & .120 & 1.430 & 249 & .154 \\
Social & .276 & .600 & -.375 & 249 & .708 \\
\hline
\end{tabular}

To discover the differences between males and females according to their thinking styles the means and standard deviation for both were computed, followed by t-test. Table 3 demonstrates that there is a little difference between males and females in terms of thinking styles. In order to further analyze the third hypothesis whether there was difference between male and female participants thinking styles a t-test was carried out after Descriptive Statistics were examined. As it is shown in the Table 3.1, the differences between the thinking styles of male and female is meaningful for External, Global, Executive, Legislative and observed t-values are $<0.05$ level of significance with 249 degrees of freedom. In other words males have used more global thinking style with $\mathrm{t}=2.103, p<0.036$ also in legislative thinking style they showed a difference with $\mathrm{t}=2.443, p<0.015$. The Table 3.1, shows that females tend to use more executive thinking styles than males with $\mathrm{t}=2.331, p<0.021$ also in external style a difference with $\mathrm{t}=3.074, p<0.002$ was seen. Other differences between males and females thinking styles were not observed. The results show that males tend to use more global and legislative thinking styles but females prefer executive and external styles.

Table 3

Descriptive statistics for males and females related to the Thinking Styles

\begin{tabular}{llrrrr}
\hline \multicolumn{1}{c}{ Items } & \multicolumn{1}{c}{ Gender } & $\mathrm{N}$ & Mean & $S D$ & \multicolumn{2}{c}{$S E$} \\
\hline Legislative & Female & 169 & 18.86 & 3.220 & .248 \\
& Male & 82 & 19.95 & 3.482 & .384 \\
\hline Judicial & Female & 169 & 18.55 & 3.615 & .278 \\
& Male & 82 & 18.59 & 2.960 & .327 \\
\hline Hierarchic & Female & 169 & 18.86 & 2.880 & .222 \\
& Male & 82 & 18.56 & 4.442 & .491 \\
\hline Global & Female & 169 & 15.98 & 2.504 & .277 \\
& Male & 82 & 16.78 & 2.997 & .231 \\
\hline
\end{tabular}


Khodae Balestane, M., Hashemnezhad, H., \& Javidi, Sh.

Table 3 ... continue

Descriptive statistics for males and females related to the Thinking Styles

\begin{tabular}{llrlll}
\hline \multicolumn{1}{c}{ Items } & \multicolumn{1}{c}{ Gender } & $\mathrm{N}$ & Mean & $S D$ & $S E$ \\
\hline Liberal & & & & & \\
& Female & 169 & 18.52 & 3.544 & .273 \\
& Male & 82 & 18.96 & 3.433 & .379 \\
\hline Executive & Female & 169 & 18.86 & 3.756 & .289 \\
& Male & 82 & 18.85 & 3.837 & .424 \\
\hline Local & Female & 169 & 17.41 & 2.999 & .231 \\
& Male & 82 & 16.80 & 3.121 & .345 \\
\hline Monarchic & Female & 169 & 18.45 & 4.161 & .459 \\
& Male & 82 & 18.80 & 4.051 & .312 \\
\hline Conservative & Female & 169 & 18.04 & 3.645 & .280 \\
& Male & 82 & 16.83 & 4.230 & .467 \\
\hline Anarchy & Female & 169 & 18.47 & 3.810 & .293 \\
& Male & 82 & 18.16 & 4.227 & .467 \\
\hline Oligarchic & Female & 169 & 18.85 & 3.516 & .270 \\
& Male & 82 & 18.10 & 2.774 & .306 \\
\hline Internal & Female & 169 & 15.96 & 3.366 & .259 \\
& Male & 82 & 16.73 & 2.239 & .247 \\
\hline External & Female & 169 & 19.57 & 2.114 & .233 \\
& Male & 82 & 18.38 & 3.194 & .246 \\
\hline
\end{tabular}

Table 3.1

T-Test for males and females related to Thinking Styles

\begin{tabular}{lccccc}
\hline \multicolumn{1}{c}{ Items } & $F$ & Sig. & $t$ & $d f$ & Sig. (2-tailed) \\
\hline Legislative & .718 & .398 & -2.443 & 249 & .015 \\
Judicial & 3.117 & .079 & -.076 & 249 & .939 \\
Hierarchic & 9.349 & .002 & .649 & 249 & .517 \\
Global & 2.522 & .114 & 2.103 & 249 & .036 \\
Liberal & 2.470 & .117 & -.938 & 249 & .349 \\
Executive & .000 & .986 & 2.331 & 249 & .021 \\
Local & .002 & .962 & 1.475 & 249 & .141 \\
Monarchic & .176 & .675 & .632 & 249 & .528 \\
Conservative & .017 & .897 & .009 & 249 & .993 \\
Anarchy & .394 & .531 & .592 & 249 & .554 \\
Oligarchic & 18.325 & .000 & 1.702 & 249 & .090 \\
Internal & 17.497 & .000 & -1.872 & 249 & .062 \\
External & 16.147 & .000 & -3.074 & 249 & .002 \\
\hline
\end{tabular}

The first finding of this study that there is a positive relationship between thinking styles and language learning strategies supports (Zhang \& Sternberg, 2000) study which they examined the relationship between learning approaches and thinking styles in two Chinese populations and found that the learning approaches and thinking styles were related.

Based on the second finding of this study, males used more compensation, memory, cognitive, and metacognitive strategies compared with females. There was no significant difference between male and female with regard to the affective and social strategy use. Current finding is in the same line as Tercanlioglu (2004) study which investigated 184 Turkish university students and discovered that males used more strategies than females. Anugkakul (2011) compared language learning strategies (LLS) employed by 72 Chinese and Thai students and found that gender and nationality had a significant effect on the students ' use of overall LLS. Tran (1988) study revealed less strategy use of Vietnamese female immigrants to the U.S. in comparison with males. Wharton (2000) found the same result that males used more strategies than females. The findings of the present research reject the results of the studies that revealed among males and females no significant difference was in 
The relationship between language learning strategies and thinking styles of Iranian EFL learners

strategy use (Shmais, 2003; Rahimi, Riazi, \& Seyf, 2004; McMullen, 2008; Endaweke, 2008).

The last finding of the present study revealed that females tend to use more executive and external thinking styles, but males prefer legislative and global styles. The results of this research are in accordance with Zhang and Sachs (1997) study which showed male participants scored significantly higher on the global thinking style than did their female counterparts. The study of Turki (2012) indicated that males rated themselves highly in the legislative and judicial style and females in executive style. The study of Sternberg (1997) indicated that legislative, global, and internal came to the favor of males. Razavi and Shiri (2005) speculated that females thinking styles marks as a whole were higher than males thinking styles but males used more global, conservative and legislative thinking styles. This study rejects the results of the studies which revealed that male students scored significantly higher on the judicial style than the female students (Sternberg \& Zhang, 2001). Shokri, Kadivar, Farzad, and Daneshvar Pour (2006) concluded that female university students showed more legislative, judicial, hierarchical, internal and external thinking styles than males.

\section{Conclusion and implications}

The results obtained from the present study are more revealing that there is a significant difference between males and females in terms of strategy choice. It was found that the differences between the strategy use of male and female are meaningful for memory, metacognitive, compensation, cognitive. In other words, males used more memory, cognitive, compensation and metacognitive strategies compared with females, but there was no significant difference between males and females with regard to the affective and social strategy use. Teachers should take care not to label students. Furthermore, they should attempt to develop other abilities of students to expand their spectrum of learning preferences.

Gender differences in styles have been the focus of many style studies. This study investigated the relationship between thinking styles and gender. The findings indicated that females tend to use more executive and external thinking styles, but males prefer legislative and global styles. The study of Sternberg (1997) indicated that legislative, global, and internal came to the favor of males. Current study demonstrated that particular thinking styles predisposed students to particular teaching styles. Furthermore, the results revealed that there is a positive correlation between thinking styles and language learning strategies. It is obvious that the ways the teachers were taught or learned, affect their teaching. The negative effects both on the learner and teacher may arise because of the difference between teaching style and learning styles. The results imply that teachers alternate their methods of instruction and assessment to accommodate the thinking and learning styles of students. Students should be receptive to teaching styles that are same as, complementary to, or distinct from their own learning styles. Syllabus planners and material designers should work out on language learning syllabi that are in line with students' perceptions and experiences. There are different factors like thinking styles, motivation, gender, and cultural issues that may influence the sort of learning that takes place. It is essential for teachers to be knowledgeable about all the factors that influence learning and increase the learning strategies of their students. Some teachers only read textbooks in the classroom and lack good knowledge of effective teaching skills. This may result from a lack of teacher training. It is necessary to initiate some learn-to-teach programs to enrich teachers' styles.

\section{References:}

Anugkakul, G. (2011). A comparative study in language learning strategies of Chinese and Thai students: A case study of Suan Sunandha Rajabhat University. European Journal of Social Sciences, 19(2), 163-174.

Cohen, A. D. (1998). Strategies in learning and using a second Language. Cambridge: Cambridge University Press.

Endaweke, A. (2008). EFL learning strategy use: The case of male and female preparatory students. Unpublished Masteral thesis, Department of Foreign Languages and Literature, Institute of Language Studies, Addis Ababa University. 
Khodae Balestane, M., Hashemnezhad, H., \& Javidi, Sh.

Felder, M. R. (1995). Learning and teaching styles in foreign and second language education. Foreign Language Annals, 28(1), 21-31. http://dx.doi.org/10.1111/j.1944-9720.1995.tb00767.x

Gavriilidou, Z., \& Papanis, A. (2010). A preliminary study of learning strategies in foreign language instruction: Students' beliefs about strategy use. Advances in Research on Language Acquisition Teaching: Selected Papers, 5, 221-231.

Golshkooh, F., Ahadi, H., Enayate, S., Asgare, P., Heydari, A., \& Pasha, Gh. (2009). The relationship between thinking styles, achievement and creativity with entrepreneur of university students. New Findings in Psychology, 4(10), 105-118.

Green, J. M., \& Oxford, R. (1995). A closer look at learning strategies, L2 proficiency, and gender. TESOL Quarterly, 29, 261-297. http://dx.doi.org/10.2307/3587625

Griffiths, C. (2007). Language learning strategies: Student`s and teacher`s perception. ELT Journal, 61(2), 91-99. http://dx.doi.org/10.1093/elt/ccm001

Hyland, T. (1993). Training, competence and expertise in teacher education. Journal of Teacher Development, 2 (2), 117-122.

Imamipour, S., \& Seyf, A. (2003). A study on development of thinking styles in the students of schools and university and its relation with creativity and academic achievement. Innovation in Education Journal, 10(3), 35-45.

Khoeiny, F. (2006). The study of relation between thinking styles and the students creativity. Quarterly Scientific Journal of Management, 5(2), 72-77.

McMullen, M. G. (2008). Using language learning strategies to improve the writing skills of Saudi EFL students: Will it really work? Unpublished Doctoral dissertation, Indiana University of Pennsylvania.

O'Malley, J. M., \& Chamot, A. U. (1990). Learning strategies in second language acquisition. Cambridge, UK: Cambridge University Press. http://dx.doi.org/10.1017/CBO9781139524490

Oxford, R. L. (1990). Language learning strategies: What every teacher should know. Boston: Heinle \& Heinle.

Oxford, R. L. (1993). Instructional implications of gender differences in L2 learning styles and strategies. Applied Language Learning, 4(2), 65-94.

Oxford, R. L., \& Burry-stock, J. A. (1995). Assessing the use of language learning strategies worldwide with the ESL/EFL version of the Strategy Inventory for Language Learning (SILL). System, 23(1), 1-23. http://dx.doi.org/10.1016/0346-251X(94)00047-A

Oxford, R., \& Nyikos, M. (1989). Variables affecting choice of language learning strategies by university students. Modern Language Journal, 73, 291-300. http://dx.doi.org/10.1111/j.1540-4781.1989.tb06367.x

Rahimi, M., Riazi, A., \& Seyf, S. (2004). An investigation into the factors affecting the use of language learning strategies by Persian EFL learners. Retrieved December 16, 2011, from http://www.aclacaal.org/Revue/vol-11-no2-art-rahimi-riazi-saif.pdf

Razavi, A., \& Shiri, A. (2005). Comparative study on thinking styles of boys and girls of high school and their academic achievement. Innovation in education Journal, 12(4), 35-45.

Sarvghad, S., Rezaee, A., \& Masomi, F. (2010). On the relationship between thinking styles and self-efficacy of pre-university students in Shiraz. Journal of Woman and Society, 2(4), 133-154.

Shmais, W. A. (2003). Language learning strategy use in Palestine. TESL-EJ, 7(2), 1-13.

Shokri, O., Kadivar, P., Farzad, V., \& Daneshvar Pour, Z. (2006).Thinking styles and learning approaches in relation to students' academic achievement. Advances in cognitive Science, 8(2), 44-52.

Sternberg, R. J. (1993). Intellectual styles: Theory and classroom implications. In B. Z. Pressesen (Ed.), Learning and thinking styles: Classroom interaction (pp. 8-42). Washington, DC: National Education Association of the United States Research for Better Schools.

Sternberg, R. J. (1997). Thinking styles. New York: Cambridge University Press. http://dx.doi.org/10.1017/CBO9780511584152

Sternberg, R. J., \& Wagner, R. K. (1992). Thinking styles inventory. Unpublished Masteral thesis, Yale University, New Haven, CT.

Sternberg, R. J., \& Zhang, L. F. (2001). Perspectives on thinking, learning and cognitive styles. Mahwah, NJ: 
Lawrence Erlbaum Associates.

Tercanlioglu, L. (2004). Exploring gender effect on adult foreign language learning strategies. Issues in Educational Research, 14(2), 181-193.

Tran, T. (1988). Sex differences in English language acculturation and learning strategies among Vietnamese adults aged 40 and over in the United States. Sex Roles, 19, 747-758. http://dx.doi.org/10.1007/BF00288990

Turki, J. (2012). Thinking styles "In Light of Sternberg's Theory" prevailing among the students of Tafila Technical University and its relationship with some variables. American International Journal of Contemporary Research, 2(3), 140-152.

Wharton, G. (2000). Language learning strategy use of bilingual foreign language learners in Singapore. Language Learning, 50, 203-243. http://dx.doi.org/10.1111/0023-8333.00117

Zhang, L. F. (2000). Are thinking styles and personality types related? Educational Psychology, 20(3), 271-283. http://dx.doi.org/10.1080/713663742

Zhang, L. F., \& Sachs, J. (1997). Assessing thinking styles in the theory of mental self-government: A Honk Kong validity study. Psychological Reports, 81(3), 915-928. http://dx.doi.org/10.2466/pr0.1997.81.3.915

Zhang, L. F., \& Sternberg, R. J. (2000). Are learning approaches and thinking styles related? A study in two Chinese populations. Journal of Psychology, 134(5), 469-489. http://dx.doi.org/10.1080/00223980009598230 


\section{Appendix A}

\section{Oxford's (1990) Strategy Inventory for Language Learning (SILL)}

Read each statement carefully and decide how well it describes you. Use the scale provided to indicate how well the statement fits the way you typically do things at school, at home, or on a job. There is no right or wrong answer. Please read each statement. Check the number on the scale that best indicates how well the statement describes you. Please proceed at your own pace. Do not spend too much time on any one statement.

Gender: Male Female

Age:

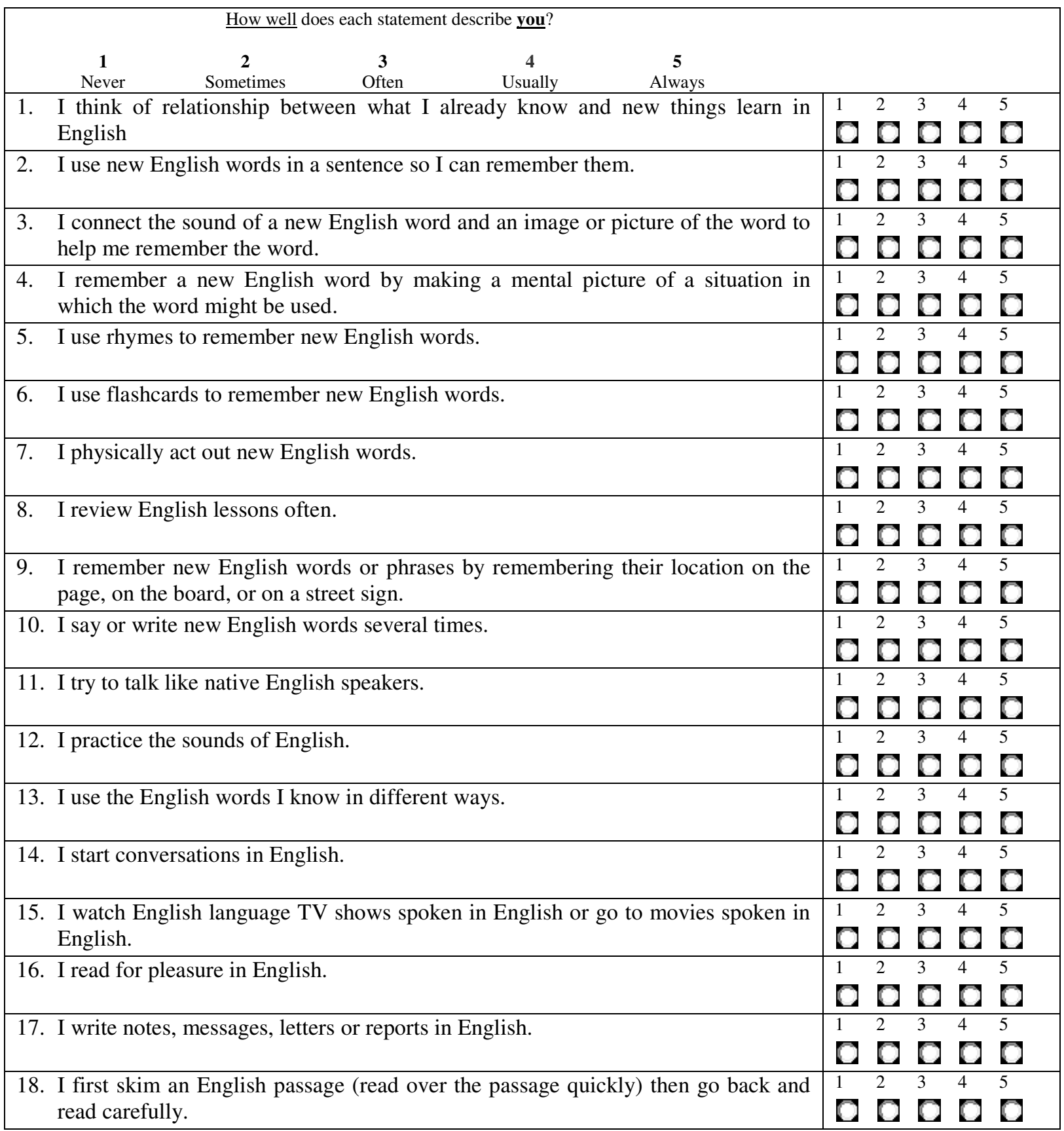


19. I look for words in my own language that are similar to new words in English.

20. I try to find patterns in English.

$\begin{array}{lllll}1 & 2 & 3 & 4 & 5\end{array}$

$\mathrm{OOOOO}$

0000

21. I find the meaning of an English word by dividing it into parts that I understand.

$\begin{array}{lllll}1 & 2 & 3 & 4 & 5 \\ \mathbf{D} & \mathbf{D} & \mathbf{D} & \mathbf{D} & \mathbf{D}\end{array}$

22. I try not to translate word-for-word.

D D D D

23. I make summaries of information that I hear or read in English.

D D D D

24. To understand unfamiliar English words, I make guesses.

D D D D

25. When I can't think of a word during a conversation in English, I use gestures.

$\begin{array}{lllll}1 & 2 & 3 & 4 & 5\end{array}$

$0 \mathrm{O} \mathrm{O}$

26. I make up new words if I do not know the right ones in English.

$\begin{array}{lllll}1 & 2 & 3 & 4 & 5 \\ 0 & 0 & 0 & 0 & 0\end{array}$

27. I read English without looking up every new word.

$\begin{array}{lllll}1 & 2 & 3 & 4 & 5\end{array}$

D D D D

28. I first skim an English passage (read over the passage quickly) then go back and read carefully.

29. I look for words in my own language that are similar to new words in English.

D D D D

$\begin{array}{lllll}1 & 2 & 3 & 4 & 5\end{array}$

D D D D

30. I try to find patterns in English. $\quad$\begin{tabular}{lllll}
\hline & 2 & 3 & 4 & 5
\end{tabular}

31. I find the meaning of an English word by dividing it into parts that I understand.

व $\mathrm{d}$ o D $\mathrm{D}$

32. I try not to translate word-for-word.

D D D D D

$\begin{array}{lllll}1 & 2 & 3 & 4 & 5\end{array}$

0000

33. I make summaries of information that I hear or read in English.

$\begin{array}{lllll}1 & 2 & 3 & 4 & 5 \\ 0 & \bigcirc & \bigcirc & 0 & 0\end{array}$

34. To understand unfamiliar English words, I make guesses.

$\begin{array}{lllll}1 & 2 & 3 & 4 & 5 \\ \mathbf{D} & \mathbf{D} & \mathbf{D} & \mathbf{D} & \mathbf{D}\end{array}$

35. When I can't think of a word during a conversation in English, I use gestures.

D D D D D

36. I make up new words if I do not know the right ones in English.

D D D D D

37. I read English without looking up every new word.

0000

38. I try to guess what the other person will say next in English.

$\begin{array}{llllll}1 & 2 & 3 & 4 & 5\end{array}$

0000

39. If I can't think of an English word, I use a word or phrase that means the same thing.

$\begin{array}{lllll}1 & 2 & 3 & 4 & 5 \\ 0 & 0 & 0 & 0 & 0\end{array}$

40. I try to find as many ways as I can to use my English.

$\begin{array}{lllll}1 & 2 & 3 & 4 & 5 \\ 0 & 0 & 0 & 0 & 0\end{array}$

41. I notice my English mistakes and use that information to help me do better.

D $\mathbf{D} \mathbf{0} \mathbf{Q} \mathbf{Q}$

42. I play attention when someone is speaking English.

1234

43. I try to find out how to be a better learner of English.

$\begin{array}{lllll}1 & 2 & 3 & 4 & 5\end{array}$

$\mathrm{OQDQD}$

44. I plan my schedule so I will have enough time to study English.

D D D D 
Khodae Balestane, M., Hashemnezhad, H., \& Javidi, Sh.

\begin{tabular}{|c|c|c|c|c|}
\hline 45. I look for people I can talk to in English. & $\begin{array}{ll}1 & 2 \\
0 & 0\end{array}$ & & $\begin{array}{l}4 \\
0\end{array}$ & 5 \\
\hline 46. I look for opportunities to read as much as possible in English. & $\begin{array}{ll}1 & 2 \\
0 & 0\end{array}$ & 3 & $\begin{array}{l}4 \\
0\end{array}$ & 5 \\
\hline 47. I have clear goals for improving my English skills. & $\begin{array}{ll}1 & 2 \\
0 & 0\end{array}$ & 3 & $\begin{array}{l}4 \\
0\end{array}$ & 5 \\
\hline 48. I think about my progress in learning English. & $\begin{array}{ll}1 & 2 \\
0 & 0\end{array}$ & $\begin{array}{l}3 \\
0\end{array}$ & $\begin{array}{l}4 \\
0\end{array}$ & 5 \\
\hline 49. I try to relax whenever I feel afraid of using English. & $\begin{array}{ll}1 & 2 \\
0 & 0\end{array}$ & $\begin{array}{l}3 \\
0\end{array}$ & $\begin{array}{l}4 \\
0\end{array}$ & $\mathbf{O}$ \\
\hline 50. I encourage myself to speak English even when I am afraid of making a mistake. & $\begin{array}{ll}1 & 2 \\
0 & 0\end{array}$ & & 4 & 5 \\
\hline 51. I give myself a reward or treat when I do well I English. & $\begin{array}{ll}1 & 2 \\
0 & \end{array}$ & $\begin{array}{l}3 \\
0\end{array}$ & $\begin{array}{l}4 \\
0\end{array}$ & 5 \\
\hline 52. I notice if I am tense or nervous when I am studying or using English. & $\begin{array}{ll}1 & 2 \\
0 & 0\end{array}$ & & & 5 \\
\hline 53. I write down my feelings in a language learning diary. & $\begin{array}{ll}1 & 2 \\
0 & 0\end{array}$ & $\begin{array}{l}3 \\
0\end{array}$ & $\begin{array}{l}4 \\
0\end{array}$ & 5 \\
\hline 54. I talk to someone else about how I feel when I am learning English. & $\begin{array}{ll}1 & 2 \\
0 & \mathrm{C}\end{array}$ & & & 5 \\
\hline $\begin{array}{l}\text { 55. If I do not understand something in English, I ask the other person to slow down } \\
\text { or say it again. }\end{array}$ & $\begin{array}{ll}1 & 2 \\
0 & 0\end{array}$ & & 4 & 5 \\
\hline 56. I ask English speakers to correct me when I talk. & 12 & & Q & O \\
\hline 57. I practice English with other students. & $\begin{array}{ll}1 & 2 \\
0 & 0\end{array}$ & & 4 & \\
\hline 58. I ask for help from English speakers. & $\begin{array}{ll}1 & 2 \\
0 & 0\end{array}$ & 3 & $\begin{array}{l}4 \\
0\end{array}$ & 5 \\
\hline 59. I ask questions in English. & $\begin{array}{ll}1 & 2 \\
0 & 0\end{array}$ & 3 & $\begin{array}{l}4 \\
0\end{array}$ & 5 \\
\hline 60. I try to learn about the culture of English speakers. & $\begin{array}{ll}1 & 2 \\
0 & 0 \\
\end{array}$ & 3 & $\begin{array}{l}4 \\
0\end{array}$ & \\
\hline
\end{tabular}




\section{Appendix B}

\section{Thinking Styles Questioner (Sternberg \& Wagner, 1991)}

Read each statement carefully and decide how well it describes you. Use the scale provided to indicate how well the statement fits the way you typically do things at school, at home, or on a job. There is no right or wrong answer. Please read each statement. Check the number on the scale that best indicates how well the statement describes you. Please proceed at your own pace. Do not spend too much time on any one statement.

Gender: Male Female

Age:

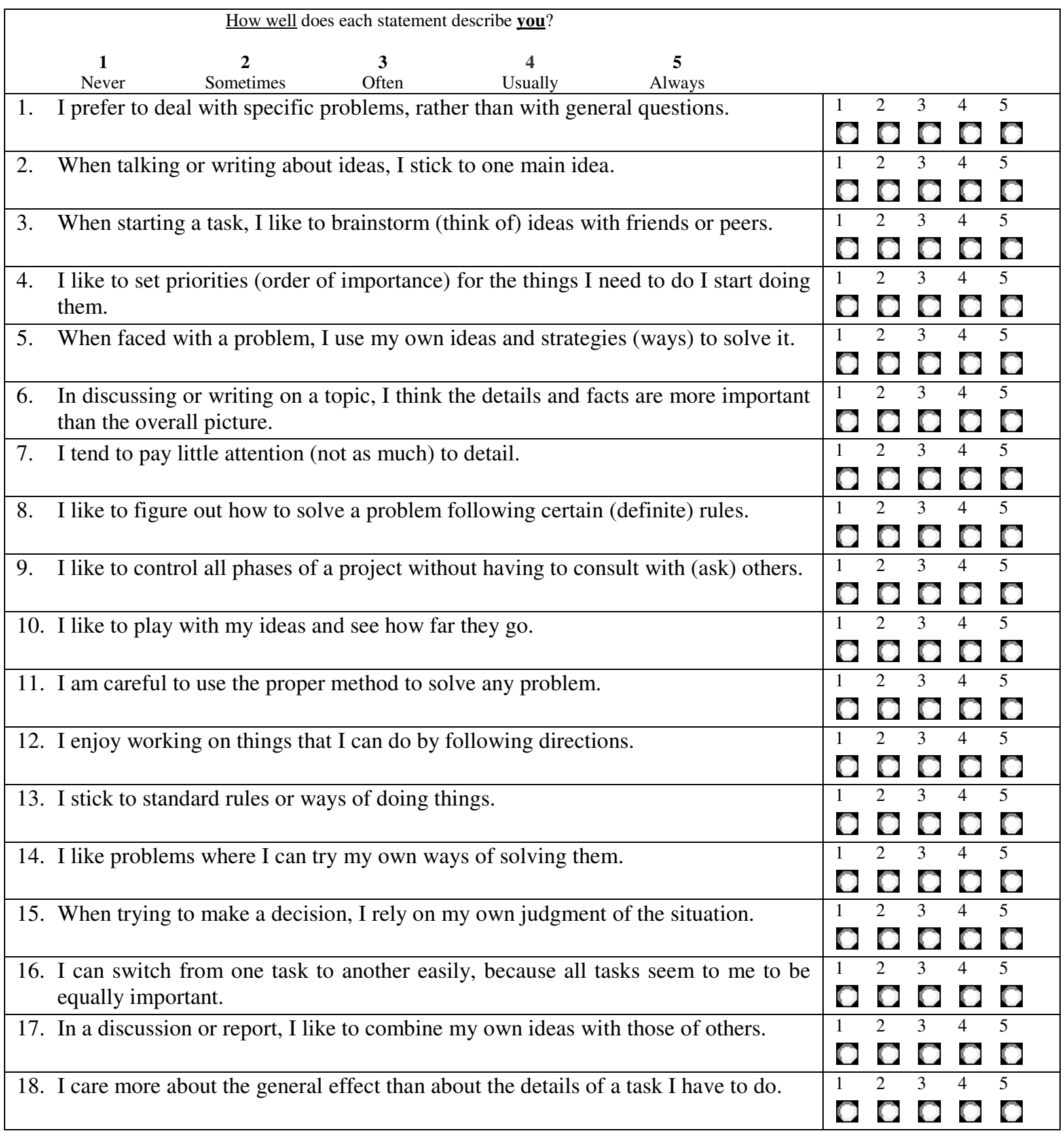


19. When working on a task, I can see how the parts relate to the overall goal of the task.

20. I like situations where I can compare and rate different ways of doing things.

00000

$\begin{array}{lllll}1 & 2 & 3 & 4 & 5\end{array}$

D D D D

21. When there are many important things to do, I try to do as many as I can in whatever time I have.

0000

22. When I am in charge of something, I like to follow methods and Ideas used in the past.

$\begin{array}{llllll}1 & 2 & 3 & 4 & 5\end{array}$

D D D D

23. I like to check and rate opposing points of view or conflicting ideas.

D D O D D

24. I like to collect detailed or specific information for projects on which I work.

$\begin{array}{lllll}1 & 2 & 3 & 4 & 5\end{array}$

D D D D D

25. In dealing with difficulties, I have a good sense of how important each of them is and in what order to tackle them.

26. I like situations where I can follow a set routine.

$\begin{array}{lllll}1 & 2 & 3 & 4 & 5 \\ 0 & 0 & 0 & 0 & 0\end{array}$

$\mathrm{OQ0Q0}$

$\mathrm{D} \mathrm{O} \mathrm{Q}$

27. When discussing or writing about a topic, I stick to points of view accepted by my colleagues.

00000

28. I like tasks and problems that have fixed rules to follow in order to complete them.

29. I prefer to work on a project or task that is acceptable to and approved by my peers.

00000

30. When there are several important things to do, I do those most important to me and my colleagues (peers).

31. I like projects that have a clear structure and set plan and goal.

$\begin{array}{lllll}1 & 2 & 3 & 4 & 5\end{array}$

D D D D

D D D D D

$\begin{array}{lllll}1 & 2 & 3 & 4 & 5\end{array}$

D D D D D

32. When working on a task, I like to start with my own ideas.

000

33. When there are many things to do, I have a clear sense of order in which to do them.

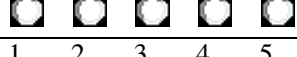

D D D D

34. I like to participate in activities where I can interact with others as a part of a team.

0000

35. I like to tackle all kinds of problems, even seemingly trivial (unimportant) ones.

36. When faced with a problem, I like to solve it in a traditional (usual) way.

0 O O O

37. I like to work alone on a task or problem.

D D D D D

$\begin{array}{lllll}1 & 2 & 3 & 4 & 5\end{array}$

D D D D

38. I tend to emphasize the general aspect of issues or the overall effect of a project.

39. I like to follow definite rules or directions when solving a problem or doing a task.

40. When discussing or writing down ideas, I use whatever comes to mind.

D D D D D

$\begin{array}{lllll}1 & 2 & 3 & 4 & 5\end{array}$

00000

$\begin{array}{lllll}1 & 2 & 3 & 4 & 5\end{array}$

0000

41. When working on a project, I like to share ideas and get input from other people.

42. I like projects where I can study and rate different views or ideas.

0000

$\begin{array}{lllll}1 & 2 & 3 & 4 & 5\end{array}$

a D D D

43. When trying to make a decision, I tend to see only one major factor.

\begin{tabular}{lllll}
1 & 2 & 3 & 4 & 5 \\
$\mathbf{D}$ & $\mathbf{D}$ & $\mathbf{Q}$ & $\mathbf{Q}$ & $\mathbf{Q}$ \\
\hline
\end{tabular}

44. I like problems where I need to pay attention to details.

D $\mathbf{D} \mathbf{Q} \mathbf{Q} \mathbf{Q}$ 


\begin{tabular}{|c|c|c|c|c|c|}
\hline 45. I like to challenge old ideas or ways of doing things and $\mathrm{s}$ & 1 & & Q & & 5 \\
\hline 46. I like situations where I interact with others and everyone works together. & 1 & 2 & 3 & 4 & $\begin{array}{l}5 \\
0\end{array}$ \\
\hline $\begin{array}{l}\text { 47. I like working on projects that deal with general issues and not with nitty-gritty } \\
\text { details. }\end{array}$ & 1 & 2 & 3 & 4 & $\begin{array}{l}5 \\
0\end{array}$ \\
\hline 48. I like situations where I can use my own ideas and ways of doing things. & 1 & 2 & 3 & 4 & $\begin{array}{l}5 \\
0\end{array}$ \\
\hline 49. If there are several important things to do, I do the ones most important to me. & 1 & $\begin{array}{l}2 \\
0\end{array}$ & $\begin{array}{l}3 \\
0\end{array}$ & $\begin{array}{l}4 \\
0\end{array}$ & $\begin{array}{l}5 \\
0\end{array}$ \\
\hline 50. If there are several important things to do, I do the ones most important to me. & $\begin{array}{l}1 \\
0\end{array}$ & $\begin{array}{l}2 \\
0\end{array}$ & $\begin{array}{l}3 \\
0\end{array}$ & $\begin{array}{l}4 \\
0\end{array}$ & $\begin{array}{l}5 \\
0\end{array}$ \\
\hline 51. I prefer tasks or problems where I can grade designs or methods of others. & $\begin{array}{l}1 \\
0\end{array}$ & $\begin{array}{l}2 \\
0\end{array}$ & $\begin{array}{l}3 \\
0\end{array}$ & $\begin{array}{l}4 \\
\mathrm{D}\end{array}$ & $\begin{array}{l}5 \\
0\end{array}$ \\
\hline $\begin{array}{l}\text { 52. When there are several important things to do, I pick the ones most important to } \\
\text { my friends and colleagues (peers). }\end{array}$ & $\begin{array}{l}1 \\
0\end{array}$ & $\begin{array}{l}2 \\
0\end{array}$ & $\begin{array}{l}3 \\
0\end{array}$ & $\begin{array}{l}4 \\
\mathrm{D}\end{array}$ & $\begin{array}{l}5 \\
0\end{array}$ \\
\hline $\begin{array}{l}\text { 53. When faced with a problem, I prefer to try new strategies (ways) or methods to } \\
\text { solve it. }\end{array}$ & 1 & 2 & 3 & $\begin{array}{l}4 \\
\mathbf{Q}\end{array}$ & $\begin{array}{l}5 \\
\mathbf{Q}\end{array}$ \\
\hline 54. I like to concentrate on one task at a time. & 1 & 2 & 3 & 4 & $\begin{array}{l}5 \\
\mathbf{Q}\end{array}$ \\
\hline 55. Like projects that I can complete independently. & 1 & 2 & & $\begin{array}{l}4 \\
\mathbf{Q}\end{array}$ & $\begin{array}{l}5 \\
\mathbf{D}\end{array}$ \\
\hline $\begin{array}{l}\text { 56. When starting something, I like to make a list of things to do and to order things } \\
\text { by importance. }\end{array}$ & 1 & 2 & 3 & 4 & 5 \\
\hline $\begin{array}{l}\text { 57. When working on a task, I can see how the parts relate to the overall goal of the } \\
\text { task. }\end{array}$ & 1 & 2 & 3 & 4 & 5 \\
\hline 58. I like situations where I can compare and rate different ways of doing things. & 1 & Q & 3 & & 5 \\
\hline $\begin{array}{l}\text { 59. When there are many important things to do, I try to do as many as I can in } \\
\text { whatever time I have. }\end{array}$ & 1 & 2 & 3 & 4 & 5 \\
\hline $\begin{array}{l}\text { 60. When I am in charge of something, I like to follow methods and Ideas used in the } \\
\text { past. }\end{array}$ & $\begin{array}{l}1 \\
0\end{array}$ & 2 & $\begin{array}{l}3 \\
0\end{array}$ & $\begin{array}{l}4 \\
\mathrm{D}\end{array}$ & $\begin{array}{l}5 \\
0\end{array}$ \\
\hline 61. I like to check and rate opposing points of view or conflicting ideas. & $\begin{array}{l}1 \\
0\end{array}$ & $\begin{array}{l}2 \\
0\end{array}$ & $\begin{array}{l}3 \\
0\end{array}$ & $\begin{array}{l}4 \\
0\end{array}$ & $\begin{array}{l}5 \\
0\end{array}$ \\
\hline 62. I like to collect detailed or specific information for projects on which I work. & $\begin{array}{l}1 \\
0\end{array}$ & $\begin{array}{l}2 \\
0\end{array}$ & $\begin{array}{l}3 \\
0\end{array}$ & $\begin{array}{l}4 \\
0\end{array}$ & $\begin{array}{l}5 \\
0\end{array}$ \\
\hline $\begin{array}{l}\text { 63. In dealing with difficulties, I have a good sense of how important each of them is } \\
\text { and in what order to tackle them. }\end{array}$ & $\begin{array}{l}1 \\
0\end{array}$ & 2 & $\begin{array}{l}3 \\
0\end{array}$ & $\begin{array}{l}4 \\
\mathrm{O}\end{array}$ & $\begin{array}{l}5 \\
0\end{array}$ \\
\hline 64. I like situations where I can follow a set routine. & $\begin{array}{l}1 \\
0\end{array}$ & 2 & $\begin{array}{l}3 \\
0\end{array}$ & $\begin{array}{l}4 \\
\mathrm{O}\end{array}$ & $\begin{array}{l}5 \\
0\end{array}$ \\
\hline $\begin{array}{l}\text { 65. When discussing or writing about a topic, I stick to points of view accepted by my } \\
\text { colleagues. }\end{array}$ & $\begin{array}{l}1 \\
0\end{array}$ & 2 & $\begin{array}{l}3 \\
0\end{array}$ & D & $\begin{array}{l}5 \\
0\end{array}$ \\
\hline
\end{tabular}


Khodae Balestane, M., Hashemnezhad, H., \& Javidi, Sh. 